\title{
A would-be science?
}

\section{A history of material culture in Poland before and after the year 1989}

\section{IGOR KĄKOLEWSKI}

Cultural history as a research topic is being taken up by many historians or smaller research groups at Polish universities or academic institutions in present-day Poland. However, in the twentieth century and at the beginning of the twenty-first century there is a lack of any institution dealing with research into cultural history in accordance with its statutes-with one exception. This exception is the Institute for the History of Material Culture of the Polish Academy of Sciences (IHMC PAS), which was renamed in 1992 into the Institute of Archaeology and Ethnology of the PAS (IAE PAS). Contrary to its original and present name, its research team, which was and still is not only made up of archaeologists and ethnologists, but to a large part also of historians, has not only carried out a great deal of research into concrete problem questions of the history of material culture in the last fifty years, but is also developing the discourse on the theory and methodology of cultural history research itself. ${ }^{1}$

At the same time, the history of the IHMC PAS - which was founded at a time when Stalinism in Poland was reaching its climax-deserves attention for two reasons: On the one hand, it is an interesting example of the relationship between an academic institute and the totalitarian and later-the more liberal the regime became-authoritarian state; on the other hand it is an example of an attempt, controlled from above, to establish a new academic discipline which

1 Cf. comparing the topic of material culture and cultural studies, above all from the ethnological perspective in German: FEEST, 2003, p. 239-254; HAHN 2005; KöNIG, 2003, p. 95-118. 
would comply with the ideological requirements of the Communist leadership. In my paper I would like to examine the development phases of research on cultural history at the IHMC - today IAE-against the background of the great political changes which gave the post-war history of Poland its corresponding rhythm, including the watershed of 1989 which brought about the end of the communist People's Republic of Poland.

The history of the IHMC begins in the first post-war years when the communist power was establishing itself in Poland, and then in the period of the setting-up of the system of totalitarian suppression during the heyday of Stalinism, i.e. around the years 1949 to ca. 1953/54. ${ }^{2}$ The new communist policy of so-called methodological reconstruction began in the academic sector at the end of the forties. This reconstruction at that time consisted in revising the bases of the humanities and social sciences in the sense of Stalinist vulgar Marxism, the core of which in turn represented the concept of the philosophy of historical materialism. The Polish Academy of Sciences, founded in the 1950s, facilitated the methodological reconstruction. Its task was to centralise Polish science. The rulers' intention was that the scientists in the institutes of the PAS, cut off from teaching work at the universities, would attract other scholars to follow then and organise science following the model of the Academy of Sciences of the Soviet Union. The Institute of History of the PAS came into being in 1953. The takeover of its management by a group of ardent progressive historians - as radical Marxists, who were linked with the structures of the Polish United Workers' Party (PUWP), were called at that time - was, however, thwarted. Shortly after, the IHMC PAS was brought into being which was intended to propagate the new specifically Marxist scientific branch-the history of material culture. At the same time, the IHMC was intended to become a platform for interdisciplinary research within the triangle: Archaeology-Ethnography-History of Material Culture. In concrete terms, its task was to link together research problems of so-called prehistoric and early medieval archaeology, classical archaeology, the history of the material culture of the Middle Ages and the Modern Period, as well as ethnography.

From 1949 on, at the latest, its development was accompanied by a wide methodological debate. Its key participant was Prof. Kazimierz Majewski-a Classical Archaeologist. Before the Second World War he had been a lecturer at the then Polish University of Lwów and at the same time supporter of Poland's Communist Party, during the Soviet occupation (1939-41 and again after 1944)

2 On the genesis as well as the organisational beginnings of the IHMC PAS cf. among others, RUTKOWSKI, 2007, p. 221f., as well as the report: Instytut, 1977, p. 448. 
he was Head of the Chair of Ancient History at the now Ukrainian-Soviet University of L'viv, after 1945 he became Professor at the University of Wrocław and finally, after 1954, first Director of the IHMC PAS. ${ }^{3}$ In his programmatic article from 1954 , he defined the history of material culture as a completely sovereign academic discipline-alongside legal and economic history-for research into the social-technical side of production, but also into so-called distribution in Marx's metalanguage, as well as consumption.

The key role in this was played by methodological-theoretical prerequisites of Karl Marx's historic materialism, in its variant richly decorated with Stalinist vulgar formulations which was regarded as the basis for the new discipline. In addition at this time it was usual and indeed necessary to include quotations from the Soviet dictator's supposed collected works in every more important publication. These ideological prerequisites can be summarised in the following way: The new Marxist history of material culture was intended to deal above all with the "social-technical, thus material side of the production process" and research into the "working implements and material products which had been created with the help of these tools, as well as people's attitude to these tools and to the forces of nature, which were utilised in production in their historical development". ${ }^{4}$

This definition is characteristic for two reasons. On the one hand, the Marxist philosophy of historical materialism, convinced, it is true of the integrity of the historical process and the need for its complex view, puts the main emphasis above all on research into the so-called basis of the historical process which is connected with the manufacture of material cultural objects. On the other hand, research into the so-called superstructure, thus the intellectual culture, was treated, if not with clear contempt, then it was at least accorded a subordinate historical significance as a consequences of the transformation in material culture.

In addition, the second main emphasis of Marxist history of material culture lay in research, above all into the technical-social side of the production process, to a smaller extent by comparison into the technical-social side of phenomena which were connected e.g. with trade or consumption. By the way, this quite simply reflected the fact that in the Communist ideology of that time the main importance was attached to industrialisation and the development of industrial production as the main factors of economic development and at the same time the significance of trade and consumption was belittled. Characteristic for the

3 RutKowsKi, 2007, p. 54.

4 Majewski, 1953/54, p. 7. 
new branch of historical science in Poland was that it fell back on the Soviet model, thus the fact that an Institute for the History of Material Culture also operated in the Soviet Union. ${ }^{5}$

At the same time, in the same number of the main organ of the IHMC, the periodical Kwartalnik Historii Kultury Materialnej (Quarterly of the History of Material Culture) - apart from the ideologised manifesto by Kazimierz Majewski ${ }^{6}$ - an authoritative text for the new field of research appeared which was only little hampered by the stylistics of the official ideology. It is an extensive study of the beginnings of the modern horse-drawn cart by Józef Matuszewski, who even before the Second World War, thanks to a scholarship at the French École des Chartres, was well acquainted with the latest French historiography. ${ }^{7}$ He adopted the theories of Richard Lefebvre de Notes, an outstanding technical historian, and "showed succinctly, almost boldly the importance of research into material culture for studies of civilisation as such". ${ }^{8}$ In his article, Matuszewski showed how the principle of the horse's harness, derived from the ancient yoke, meant that the horse, by pulling with its neck, was unable to utilise all its motor possibilities; however, Matuszewski did not agree with de Notes who claimed exaggeratedly that this had almost led to the downfall of the civilisation of Ancient Rome. At the same time, he referred to the role of the horse collar widely spread in the tenth century as an essential factor in the economic development of medieval and modern Europe.

"[...] at the same time, the study by J. Matuszewski opens our eyes for the whole sphere of feedback, which had been in darkness up to now, lying between mental, social and material culture. As a result of these positive initiations, [...] the authors and editorial board [of the VGMK-I.K.] became more sensitive to the need that the works published here are intended to show a wider cultural context".

5 ID., in particular p. 11f.

6 Cf. also later opinions by the founding father of this branch of historical studies in the People' Republic of Poland on the topic of the history of material culture: Majewski, 1957, p. 209-244; Majewski, 1960, p. 1-14; MAJewski, 1973, p. 395-409; Majewski, 1976, p. 109-115; MAJEwsKi, 1978, p. 207-218.

7 RutKowsKi, 2007, p. 48.

8 Cf. a review and analysis of the article by Matuszewski in: SzTETTYŁo, 1993, p. 23.

9 ID., p. $23 \mathrm{f}$. 
It seems that it would be a mistake to credit the creation of the Polish Historical School of Material Culture solely to Marxist inspirations and a certain ideological fashion of the Stalinist period. The real pioneer of the history of material culture as a separate field of research in Poland was probably the Poznań economic historian, Jan Rutkowski, who had already been outstanding long before the Second World War. Together with the historian Jan Bujak in Lwów, he was cofounder in 1930 of the Roczniki Dziejów Społecznych i Gospodarczych (Annals of Social and Economic History) - the Polish equivalent to the renowned French Annales, a periodical that had been founded a year before by Marc Bloch and Lucien Febvre. In this connection, it should be observed that the pre-war Polish School of Economic History of Bujak and Rutkowski, although it certainly remained under the influences of the French Annalistes in the 1930s, was born out of their own experience and formulated a similar programme to a certain degree independently of the Annales school.

Shortly after the war, at the end of his life, in the period still before the importunate Stalinist indoctrination of Polish science, Jan Rutkowski wrote two extensive texts propagating the commencement of large-scale studies on the history of material culture. ${ }^{10}$ In this connection, Rutkowski sketched out the history of the development of cultural history, beginning with Thomas Buckle and Jacob Burckhardt - the founding fathers of this branch of historical studies around the mid- $19^{\text {th }}$ century - and also illustrating the subdivision of culture and its history into the history of material, social and intellectual culture, generally accepted at that time in European scholarship. For this reason, his standpoint can be described as being holistic. He maintained that basically intellectual and material culture should not be separated from one another and that real history as a science in reality was a history of culture. At the same time, however, he stipulated the extent of the research on the history of material culture as a special field that differs with regard to the focus of interest and methods from economic or legal history. In his opinion, the history of material culture did not just integrate research into the narrowly understood history of technology and lifeless objects into itself, but also into widely understood everyday culture (the latter was nota bene-completely in accordance with the approaches of the Annales school-contrasted with the classical history of events). Rutkowski was of the opinion that the history of material culture should include interdisciplinary research, such as ethnology, archaeology and history. The complex of research

10 The second paper in the form of an incomplete methodological study only appeared in 1959, cf. RUTKOWSKI, 1959, p. 5-61; cf. a review and analysis of the concept by Jan Rutkowski in: ToPOLSKI, 1980, p. 461-467. 
themes should concern such questions as, e.g. the history of tools, industrial and agricultural technology, the history of transport and communication, the history of consumption, the material and moral bases of everyday and intellectual life, including the technical and material aspects of the history of education, the fine arts and architecture.

However, in the People's Republic of Poland in the first half of the fifties, there was only little room to pursue such a research programme into the history of material culture which would not have been ideologically burdened by Stalinism. The methodological reconstruction led to a centralisation of science, whose tool, in the opinion of the Communist rulers, should be the institutes of the Polish Academy of Sciences. The most treasured possession of this process was certainly the Institute for the History of Material Culture which was intended to integrate the research work of archaeologists and ethnographers under the dominance of the representatives of the new Marxist discipline of the history of material culture. In addition, at the beginning of the 1950s a new subject was introduced at universities: the History of Material Culture which absorbed the previously separate subjects, Archaeology and Ethnography. This attack on the sovereignty of traditional academic disciplines led to a veiled rebellion shortly afterwards, in which archaeologists played first fiddle. ${ }^{11}$

This rebellion was reflected in the votes during the wide methodological debate at the head office of the First Faculty of Social Sciences of the PAS in 1955, thus at a time when, almost eighteen months after Stalin's death, the first still timid signs of a weakening of the regime became visible. During this debate, three typical points of view were represented.

The first point of view could be described as being radical. It presupposed that a history of material culture existed as a separate social science which researched into the social-technical aspects of class societies. This point of view was also presented in the form of a completely vulgarised thesis which said that intellectual culture was above all a product of the ruling classes and therefore above all an object of research by bourgeois scholarship. On the other hand material culture had been a product of the exploited classes, and for precisely this reason it should be the main subject matter of research of truly Marxist scholars.

The second point of view, which represented a compromise so to speak, let the history of material culture come into being as an ancillary discipline which served historical science. Its supporters were in favour of an enigmatically for-

11 This debate can be reconstructed on the basis of the three texts published in Kwartalnik Historii Kultury Materialnej: KulCZYCKI, 1955, p. 519-562; HoŁubowicz, 1955 , p. 563-585 and the report of the debate: Dyskusja, 1955, p. 586-620. 
mulated decentralisation in academic policy in the further future, although at the same time they declared themselves in favour of a dominance of the history of material culture at archaeological institutes.

The third point of view, which can be described as being practical, assumed the possibility that a history of material culture did not exist as an autonomous discipline, but as a group of research topics. A large part of the prominent archaeologists, whose autonomy was endangered, spoke out in this spirit as did also experienced and openly thinking historians.

When considering this debate, it has to be pointed out that the majority of its participants, regardless of the viewpoint they represented, made use of the Marxist stylistics accepted at that time in their argumentation, often quite simply to avoid the accusation of divergent thinking or even of disloyalty towards the Communist Party. A correct deciphering of this Marxist-Stalinist slang, which would let us determine who represented which point of view, today represents a great challenge, above all for historians of the younger generation, which they can often not master. The participants in the 1955 debate gladly fell back on Soviet models in this connection. The supporters of the first viewpoint named above, who demanded the creation of a new Marxist history of material culture as a separate, progressive science, quoted the fact that the Academy of the History of Material Culture had already been founded in Petrograd in 1919, which was later transformed into the Institute for the History of Material Culture of the Soviet Academy of Sciences. Their opponents fell back on similar stylistics and similar arguments; however, they said that behind the nameplate of the Soviet IHMC in reality there was just hidden an institute of archaeology. In this connection, they claimed that ultimately the "liquidatory endeavours of the Trotzkyist vermin" 12 against archaeology as a sovereign discipline in the Soviet Union had been curbed at the beginning of the second half of the thirties, thus during Stalin's purges.

The dispute about the sovereignty of the history of material culture as a separate discipline ended in Poland with a compromise. On the one hand, it was abolished as a subject at universities, on the other hand, however, the organisational structures of the IHMC PAS were retained as an interdisciplinary platform for archaeologists, ethnographers and historians who specialised in the history of material culture. After the political breakthrough of 1956 and with the relative liberalisation of cultural and academic life in the People's Republic of Poland, the IHMC PAS continued to exist in an organisational structure little changed by comparison with the initial period, despite certain changes in the 1960s, among

12 DYSKUSJA, 1955, p. 608. 
other things after the anti-Semitic hate campaign controlled by the Communist authorities in 1968, to which many scholars, also from the academic milieu, fell victim. ${ }^{13}$

The ideological ballast decreased during the so-called thaw after 1956 which had a decisively positive influence on the quality of the research work initiated by the IHMC. The interesting thing in this connection is that, from the end of the fifties, the IHMC was the only institute in the Eastern bloc to bear the name Institute for the History of Material Culture. In its environment, the supporters of the viewpoint according to which the history of material culture represented a group of research topics, the research into which should lead to a better acquaintance with the whole of cultural history, now set the tone. ${ }^{14}$ In this connection, inspiration was openly taken from Jan Rutkowski's earlier concepts. The projects inspired at the beginning of the 1950s led to the publication of important works from the fields of economic history, as well as prehistoric and classical history, in the following decades. The research work from the field of the history of material culture concentrated above all on two epochs - the Middle Ages and the Modern Age-falling back on the following topics, among others: The history of Polish industry and Polish crafts, the settlement of the Polish territories, agriculture. The focus in this connection was also on the examination of the conditions of the material existence of different social strata.

Generally speaking, a shift of research priorities was recorded in the sixties and seventies away from topics, such as the production technology of crafts, agriculture and industry, to topics, such as the culture of everyday life, the history of communication and travel, as well as widely understood consumption. ${ }^{15}$ This was certainly a reflection of the changes in the People's Republic of Poland, where industrialisation had been carried through in the fifties and early sixties, and thus in the sixties and seventies society's notice began to concentrate on consumption, the numerous deficits of which further strengthened researchers' attention. All the more so as the new government, which had seized power after the strikes on the Baltic coast in December 1970, made the increase in society's level of consumption into one of its most important propaganda slogans.

In addition, the shift in research priorities, above all to themes of the culture of everyday life, the history of communication and consumption, was due more

13 On the organisational changes in the structure of the IHMC PAS see among other things the report: DZiąalność, 1970, p. 727f.

14 Among others, the outstanding Polish medievalist Aleksander Gieysztor proposed such a perspective: GIEYSZTOR, 1958, p.143-154.

15 SZTETYŁŁo, 1993, p. 24 f. 
and more to the popularity of the works of the classical writers of the French Annales school, that had been translated into Polish, as well as Polish historians' active contacts with this milieu. After 1956, this active intellectual exchange was possible for younger Polish historians, mainly thanks to a wave of scholarships for France, financed, of course, by the French government. It can probably be asserted without exaggeration that, above all at the end of the fifties and in the sixties, French historiography, in particular the Annales school, represented the proverbial window of the world for Polish historiography. By the way, the fact that IHMC archaeologists conducted excavations on medieval sites, e.g. in the Côte d'Or and in Aveyron, ${ }^{16}$ can give evidence of the importance of the contacts with the École Practique des Hautes Études (IV section).

All this was reflected in the methodological debates in IHMC circles. Particular attention was paid in the discussion at the end of the sixties and beginning of the seventies to the first volume of the Civilisation materiélle et capitalisme by Fernand Braudel published in 1967. The pragmatists, who defended the viewpoint of the integrity of material culture with culture as such, now made use of the Annalistes' concepts, which in turn called the autonomy of the history of material culture as a separate discipline into question. Let us here quote a voice from the methodological discussion at the IHMC in 1971:

"The attempts by contemporary French historiography here are interesting. In the circle of the well-known periodical 'Annales ESC', a series of monographs on selected questions of material culture has appeared which as a rule take up the involvement of human beings in the shaping of this culture; on the other hand, they avoid presenting the history of objects, e.g. the history of resources, tools, etc., without associating them with the respective social group. Following this series of monographs, a methodologically innovative work by Prof. F. Braudel, Civilisation materielle et capitalisme appeared. In its introductory section, the characteristics of the material culture of the age of capitalism are recorded micro-analytically, and people are shown in their everyday life. Consumption is to the forefront which, in the author's opinion, necessitates the development of production, both technically and economically. The whole structure of modern civilisation (its fixed and variable elements) finds expression in the social and political life of this epoch."17

16 Cf. among other things the report: DZIAŁALność, 1970, p. 732.

17 Pietrzak-PaWŁowska, 1971, p. 106. 
The new perspective fascinated and thus also shaped the scholars who defended the autonomy of the history of material culture as a separate academic discipline from a more traditional Marxist perspective. Their definition was expanded by the postulate of research works about widely understood consumption. ${ }^{18} \mathrm{Re}-$ search on the history of fashion were often also postulated in the wide context of mental and economic transformations. ${ }^{19}$

The growing influence of the historiography of the Annales school and in general the opening of Polish historiography in the seventies and eighties to worldwide research work on cultural history, which became apparent, for example, in research into widely understood structures of everyday life, into élitist culture versus popular culture, or into the newly defined history of material culture, finds its confirmation in many interesting monographs and syntheses outside the circle around the IHMC. On the other hand, in the IHMC milieu, the new direction of research, that became established in western Europe, the United States and Canada in the second half of the twentieth century under the name industrial archaeology or also postmedieval archaeology ${ }^{20}$, also convinced them of the correctness of the endeavour to discover cultural contents in material objects. At the same time, old supporters of the Marxist defined history of material culture now began to newly discover the symbolic level of [material] things, maintaining:

\footnotetext{
"We live among things and use them [...] in accordance with their intended purpose, but do not usually notice their symbolic side. However, precisely this side is a source of information for culture. They include significantly richer contents than words are capable of doing. Therefore, human beings have never limited themselves to words and use things in the exchange of ideas. Both the oil-lamp and the hammer and sickle [in symbolism, thus intellectual culture-I.K.] were newly discovered when their practical applicability had lost its significance with regard to civilisation." ${ }^{21}$
}

Despite the complete renunciation of ideological miasmas and the adoption of world-wide modern trends in cultural history research by IHMC PAS, and also despite its own creative contributions to this research work, after the watershed in 1989 and the restoration of full Polish sovereignty, this institution fell victim

18 PAZDUR, 1971, p. 85-105.

19 Dyskusja, 1971, p. 111 and 115.

20 PAZDUR, 1977, p. 457-469.

21 ID., S. 468; see also interesting comments: PAZDUR, 1973, p. 411-43. 
to a kind of revenge. A revenge - that like every vengeance-was actually irrational in itself. This revenge consisted in the fact that at the turn of the years 1991 and 1992, the IHMC was renamed Institute of Archaeology and Ethnology and the term History of Material Culture was completely deleted, although at this institute-after the archaeologists-precisely historians, who dealt with exactly this field, represented the second largest group in numbers. ${ }^{22}$ Oddly enough, in 1991, the Russian IHMC in St. Petersburg was reactivated that had been transformed into the Institute of Archaeology in 1959.

Fortunately, the change in the institute's name did not result in the dismissal of the still energetic and creative scholars dealing with the history of material culture. At present they represent the probably most numerous group of historians in Poland who deal with widely understood cultural historical research, who have an institutional framework, and-what is important in this connectionsubject their research to profound methodological reflection. ${ }^{23}$ They demand a resumption of the discussion of the theory of the history of material culture and point to the evolution of cultural history in the last 150 years, above all under the influence of structural, historical and cultural anthropology. Thus one becomes aware in what way the anthropological-cultural perspective vanquished the positivistic-substantial research perspective, that had been elaborated in the second half of the $19^{\text {th }}$ century and still dominated in the first half of the twentieth, which in its view of reality presupposed its subdivision into the intellectual and material sphere, or-in another variant-a subdivision into an intellectual, social and material culture.

In this was, the anthropological and structural perspective begins to dominate in research into the history of material culture This assumes that the "analysis of cultural phenomena may not just be based on factually compiled and separately considered elements [...]. The fundamental characteristics of the objects examined are, namely, not so much dependent on the characteristics of their substratum, 'as on the method of the composition of the elements (the internal structure) and their place in a wider context (external structure)", ${ }^{24}$

22 PAZDUR, 1977, p. 468.

23 A good example for this from the early nineties is the resumption of the discussion about the concept of the structures of everyday life and in general Braudel's concept of the history of material culture-for this cf. BoGUCKA, 1996, p. 247-253; KARPIŃSKI, 1996, p. 303-304; KowECKA, 1996, p. 255-261; SOWINA, 1994, p. 153-158; SZAROTA, 1994, p. 239-245; SZTETYŁŁO, 1994, p. 181-182; TopolsKi, 1994, p. 461467; WRZOSEK, 1994, p. 167-172.

24 TABACZYŃSKI, 1993, p. 15. 
Therefore the change in perspective for research into the history of material objects from the positivistic-substantial to the anthropological-structural one led to these objects being seen as correlates of the cultural heritage. In 1993, Stanisław Tabaczyński, a Polish archaeologist and medievalist from the generation of those who began their careers at the IHMC in the fifties, stressed in his reflection on the contemporary state of the history of material culture that material objects as such do not depict the content of culture, "which is above all a 'reality of ideas', [however,] they do hold valuable information on the culture, they perpetuate temporal and spatial dimensions of cultural phenomena". ${ }^{25}$

New theoretical approaches are being elaborated in parallel to modern research into concrete ways of looking at problems in the history of material culture. Research into the newly defined everyday life brings particularly interesting results, e.g. with regard to the Early Modern Period and the extensive archive sources, such as lists of real property and similar documents which show the history of human beings among things and vice versa: the history of things among human beings. This in turn allows us to show the changeability, but also conversely the constancy of the processes of civilisation over a longer period of time.

"In this view, the history of material culture comes directly into contact with
ethnology, it is based on the achievements of medieval and modern archae-
ology, e.g. on industrial archaeology. In this sense-one researcher of the
middle generation from the IHMC, Andrzej Pośpiech, observes-academic
archive studies of written sources, manuscript archive materials [...] could be
described as word archaeology. It discovers namely-just like an archaeolo-
gist through his excavations-archaeological monuments, sources of infor-
mation about the conditions of life in the past, often unknown, fascinating
through their exoticism and the colourful splendour of the detail“. ${ }^{26}$

If one looks from this perspective-Pośpiech adds - "the history of material culture and mentality are one and the same thing". ${ }^{27}$

At the same time, material culture historians are accompanied more and more by postmodernist awareness that our "pictures of the past are our constructions, and not just simply the past as such. In truth namely, by speaking about the past we are conducting a dialogue with one another about our culture [and at

25 ID., p. 16; cf. TOPOLSKI, 1993, p. 421-425.

26 PoŚPIECH, 1997, p. 218.

27 ID., S. 219; cf. also PośPIECH, 1996, p. 263-270. 
the same time] about their past". ${ }^{28}$ This awareness accompanies me today, too, while I present the history of Polish research into the history of material culture in rough outline.

\section{Literature}

BOGUCKA, MARIA, Życie codzienne-spory wokół profilu badań i definicji, in: Kwartalnik Historii Kultury Materialnej 44 (1996), p. 247-253.

Dyskusja na posiedzeniu plenarnym Wydziału I Nauk Społecznych Polskiej Akademii Nauk w dniu 2 lutego 1955 roku nad zagadnieniami teoretycznymi historii kultury materialnej, in: Kwartalnik Historii Kultury Materialnej 3 (1955), p. 586-620.

Dyskusja, in: Kwartalnik Historii Kultury Materialnej 19 (1971), p. 107-128.

Działalność Instytutu Historii Kultury Materialnej PAN w 1969 r., in: Kwartalnik Historii Kultury Materialnej 18 (1970), p. 727-740.

Feest, Christian F., Materielle Kultur, in: Ethnologie. Einführung und Überblick, ed. by Bettina Beer/Hans Fischer (Ethnologische Paperbacks), Berlin 2003, p. 239-254.

GIEYSZTOR, AlEKSANDER, A propos de l'histoire des conditions materielles de la vie humaine, in: Kwartalnik Historii Kultury Materialnej 6 (1958), fascicule suplement, Ergon, vol. 1, p. 143-154.

Hahn, Hans Peter, Materielle Kultur. Eine Einführung. (Ethnologische Paperbacks), Berlin 2005.

HoŁUbowicz, WŁodZIMIERZ, Uwagi o historii kultury materialnej jako nauce, in: Kwartalnik Historii Kultury Materialnej 3 (1955), p. 563-585.

Instytut Historii Kultury Materialnej Polskiej Akademii Nauk 1953-1977, in: Kwartalnik Historii Kultury Materialnej 25 (1977), p. 447-454.

KARPIŃSKI, ANDRZEJ, Everyday life - a new research trend in the history of culture, in: Kwartalnik Historii Kultury Materialnej 44 (1996), p. 303-304.

KöNIG, Gudrun M., Auf dem Rücken der Dinge. Materielle Kultur und Kulturwissenschaft, in: Unterwelten der Kultur. Themen und Theorien der volkskundlichen Kulturwissenschaft, ed. by KASPAR MAASE/BERnD JÜRGEN WARNEKEN, Köln 2003, p. 95-118.

28 Ostoja-ZagóRsKi, 1997, p. 217; cf. also OstoJA-ZAGóRSKI, 1994, p. 177-179 and finally the comments by this author on the topic of archaeology and humanities, OstoJA-ZAGÓRSKI, 2002, p. 277-286. 
KowecKA, ElżBIETA, Źródła do życia codziennego w XIX w. i metody ich badań, in: Kwartalnik Historii Kultury Materialnej 44 (1996), p. 255-261.

KULCZYCKI, JERZY, Założenia teoretyczne historii kultury materialnej, in: Kwartalnik Historii Kultury Materialnej 3 (1955), p. 519-562.

MAJEwSKI, KaZIMIERZ, Historia kultury materialnej, in: Kwartalnik Historii Kultury Materialnej 1/2 (1953/54), p. 3-26.

ID., Najnowsze badania nad historią antycznej kultury materialnej, in: Kwartalnik Historii Kultury Materialnej 5 (1957), p. 209-244.

ID., Uwagi o zakresie historii kultury materialnej i systematyce ergologicznej, in: Kwartalnik Historii Kultury Materialnej, 8 (1960), p. 1-14.

ID., Nowe uwagi do badań historii kultury materialnej antyku, in: Kwartalnik Historii Kultury Materialnej 21 (1973), p. 395-409.

ID., Dalsze uwagi o badaniu historii rzeczy, in: Kwartalnik Historii Kultury Materialnej 24 (1976), p. 109-115.

ID., Rozważań nad historią antycznej kultury materialnej ciąg dalszy, in: Kwartalnik Historii Kultury Materialnej 26 (1978), p. 207-218.

OstOJA-ZAGÓRSKI, JANUSZ, W kwestii znaczeniowych treści kultury materialnej, in: Kwartalnik Historii Kultury Materialnej, 42 (1994), p. 177-179.

ID., [voice in the discussion:] Archeologia, etnologia, historia kultury materialnej-perspektywy badań, in: Kwartalnik Historii Kultury Materialnej 45 (1997), p. 215-217.

ID., Archeologia wobec humanistycznych koncepcji badań nad kulturą, in: Kwartalnik Historii Kultury Materialnej, 50 (2002), p. 277-286.

PAZDUR, JAN, Historia kultury materialnej Polski. Doświadczenia i propozycje, in: Kwartalnik Historii Kultury Materialnej, 19 (1971), p. 85-99.

ID., Technika jako przedmiot badań historii kultury materialnej, in: Kwartalnik Historii Kultury Materialnej 21 (1973), p. 411-433.

ID., Rzeczy i środowisko materialne oraz ich historia, in: Kwartalnik Historii Kultury Materialnej 25 (1977), p. 457-469.

PietrZak-PawŁowska, Irena, [voice in the discussion:] Dyskusja, in: Kwartalnik Historii Kultury Materialnej 19 (1971), p. 106-108.

Pięćdziesiąt lat badań nad historią kultury materialnej, in: Kwartalnik Historii Kultury Materialnej 50 (2002).

PoŚPIECH, ADAM, Prowincja szlachecka w Polsce XVII wieku. Ludzie-przedmioty-życie codzienne (zarys problematyki), 44 (1996), p. 263-270.

ID., [voice in the discussion:] Archeologia, etnologia, historia kultury materialnej-perspektywy badań, in: Kwartalnik Historii Kultury Materialnej 45 (1997), p. 217-220. 
RUTKOWSKI, JAN, Historia kultury i próba systematyzacji jej zagadnień (do druku przygotował Janusz Deresiewicz), in: Kwartalnik Historii Kultury Materialnej 7 (1959), p. 5-61.

Rutkowski, Tadeusz Pawee, Nauki historyczne w Polsce 1944-1970. Zagadnienia polityczne i organizacyjne, Warszawa 2007.

SowINA URSZUla, 'Ferdynand Braudel a koncepcje historii kultury materialnej'. Dyskusja w Instytucie Archeologii i Etnologii PAN. Warszawa, 7 grudnia 1993 r., in: Kwartalnik Historii Kultury Materialnej 42 (1994), p. 153-158.

SZAROTA, ToMASz, Życie codzienne-temat badawczy czy tylko popularyzacja? (Na marginesie serii wydawniczych Hachette i PIW-u), in: Kwartalnik Historii Kultury Materialnej 42 (1994), p. 239-245.

SzTETYŁŁO, JANuSz, Nec mergitur-40 lat 'Kwartalnika Historii Kultury Materialnej', in: Kwartalnik Historii Kultury Materialnej 41 (1993), p. 23-32.

ID., 'Kwartalnik Historii Kultury Materialnej' i Ferdynand Braudel, in: Kwartalnik Historii Kultury Materialnej 42 (1994), p. 181-182.

TABACZYŃSKI, STANISŁAW, Kultura i jej rzeczowe korelaty, in: Kwartalnik Historii Kultury Materialnej 41 (1993), p. 5-20.

TOPOLSKI, JERZY, Jana Rutkowskiego koncepcja historii kultury materialnej, in: Kwartalnik Historii Kultury Materialnej 28 (1980), S. 461-467.

ID., O składnikach i korelatach kultury, in: Kwartalnik Historii Kultury Materialnej 41 (1993), p. 421-425.

ID., Ferdynand Braudel a koncepcja historii kultury materialnej, in: Kwartalnik Historii Kultury Materialnej 42 (1994), p. 159-165.

WrzoseK, WoJcIECH, Braudelowska idea kultury materialnej, in: Kwartalnik Historii Kultury Materialnej 42 (1994), p. 167-172. 
